James A. Dorn*

\title{
China's Challenge: Expanding the Market, Limiting the State
}

DOI 10.1515/me-2016-0002

Abstract: China has made significant progress since 1978 in expanding the market, but that progress is threatened by the failure to limit the state. The critical challenge facing the Chinese Communist Party (CCP) and its leadership is to widen the range of choices open to individuals by promoting what Milton Friedman, in his 1988 memorandum to General Secretary Zhao Ziyang, called "free private markets." Free markets require well-defined private property rights protected by a just rule of law. China has a robust private sector and private property rights are now recognized by law, but the state sector and state ownership continue to play a strong role in directing economic life.

Keywords: China, market

\section{Introduction}

Premier Li Keqiang (2015) tells us that reforms to cut bureaucracy and decentralize power will help "get the relationship right between the government and the market." However, without widespread privatization and a free market in ideas, as expounded by Ronald Coase and Ning Wang (2012), state power - and the rent seeking that goes with it - will continue to be a drag on individual freedom and prosperity.

Steven Cheung's prediction in 1981 that China would go capitalist by allowing the spontaneous development of the market was prescient, but he also admitted in 1988 that the endemic problem of state-protected monopolies could only be ended by selling off state assets and removing barriers to entry. Like his mentors Friedman and Coase, he called for privatization and the rule of law (Cheung 1982, 1990).

China is thus at a crossroads: the gains brought about by the spontaneous market are challenged by a powerful state more reminiscent of China's

*Corresponding author: James A. Dorn, Cato Institute, Washington, D.C., USA, E-mail: JDorn@cato.org 
dogmatically socialist past than its recent capitalist development. A one-party state that still blocks a free market in ideas, has a strong grip on banking and finance, and thinks it is possible to achieve predetermined growth rates, as if the economy is a machine, fundamentally inhibits the private processes of wealth creation. The damage China's illiberal state has inflicted on the nation is becoming evident as the economy slows, debts mount, and state-owned enterprises (SOEs) draw capital away from the more productive private sector.

President Xi Jinping has called for further economic liberalization but at the same time has done little to advance privatization, the rule of law, and limited government. He seeks to strengthen large SOEs by requiring that they operate on a commercial basis, and plans to retain them as the heart of China's socialist market economy (Wei 2015).

The problem is that without private owners and the ultimate threat of bankruptcy, socialist enterprises have little incentive to be efficient. It is well-known that China's private industrial firms have a much higher return on assets than SOEs (Lardy 2014: 121). In free private markets, firms are incentivized to be efficient and to maximize profits; firms that cannot pass the market test will fail. When government interferes with the competitive market process, the marketplace becomes politicized and the range of choices open to people becomes more limited.

This article explores the tension between the state and the market in China, the challenges that remain in moving toward free private markets, and the importance of drawing on China's ancient culture to understand the importance of freedom and limited government in promoting economic and social harmony.

\section{China's socialist market economy}

Under Deng Xiaoping, China's paramount leader from 1978 until his retirement in 1992, economic liberalization and marketization advanced - primarily from the bottom-up. When local experiments aimed at expanding market-friendly institutions were successful, they were allowed to spread and eventually sanctioned by new laws. Contractual relationships grew and replaced oppressive state controls.

The "household contract responsibility system" (baochan daohu) that replaced collective farms allowed greater freedom for farmers and resulted in the development of township and village enterprises (TVES). ${ }^{1}$ According to Deng (1987: 189),

1 For a detailed account of how farmers helped liberalize China through "a spontaneous movement," see Kate Xiao Zhou (1996: 4). 
They were like a new force that just came into being spontaneously. ... If the central Committee made any contribution in this respect, it was only by laying down the correct policy of invigorating the domestic economy. The fact that this policy has had such a favorable result shows that we made a good decision. But this result was not anything that I or any of the other comrades had foreseen; it just came out of the blue.

Many of the other reforms since 1978 have displayed this bottom-up character, and the private market sector has advanced to become the main engine of China's economy, which is now the second largest in the world (Lardy 2014). Trade liberalization, price reform, constitutional recognition of the importance of the private sector, and stronger protection of private property have all advanced the market mechanism for allocating resources and satisfying wants. In so doing, millions of people have been able to lift themselves out of poverty.

Party leaders, however, are reluctant to extend the market too far or to widen the scope of private property rights lest they lose power. While officials have allowed markets in goods and services to expand, and have privatized housing, they have continued to exercise strict control over land rights and have stifled a free market in ideas. Official documents pay homage to freedom of thought, the inviolability of "property rights of the non-public economy," and the rule of law, but the CCP provides little substantive protection of fundamental rights.

The global financial crisis of 2007-2008 expanded the role of the state and slowed the growth of the market, not only in China but around the world. President $\mathrm{Hu}$ Jintao and Prime Minister Wen Xiabao engineered a gigantic stimulus program designed to prop up SOEs via a rush of bank credit. Government intervention appeared to work as China's avoided a major recession, but marketization slowed and confidence was lost in China's reform movement. Moreover, the rush of credit going to questionable projects has led to the current rising bad debt.

When the leadership changed in March 2013, with the appointment of President Xi Jinping and Prime Minister Li Keqiang, hope for reform increased. The Third Plenum of the Eighteenth Party Congress, in November 2013, announced a new blueprint for economic reform with further price liberalization and a wider role for private firms seeking to compete with SOEs, especially in the service sector.

In its "Decision on Major Issues Concerning Comprehensively Deepening Reforms," the CCP's Central Committee emphasized that "the underlying issue is how to strike a balance between the role of the government and that of the market." The Committee advocated letting "the market play the decisive role in allocating resources" in order to "improve the socialist market economy." Hence, the free-market bird was still confined to the cage of socialism (CCP 2013).

A socialist market economy is not a free private economy. Widespread state ownership and the legacy of central planning persist, especially in the financial 
sector where state-owned banks dominate, investment decisions are heavily politicized, key interest rates are subject to government oversight, capital controls remain in force, and exchange-rate flexibility is closely regulated. This system of financial repression misallocates capital, discriminates against private firms, and deprives the Chinese people of a wide choice of investment alternatives.

While there can be no doubt that China has made considerable progress in moving from plan to market, the visible hand of government is still thwarting the invisible hand of the market. When the power of the state, under the guise of "socialism," substantially limits economic freedom and breeds rent seeking and corruption, fundamental institutional change - not piecemeal reform - is needed to shatter special interests supporting the status quo (Cheung 1990: 28-29).

\section{The relation between the individual and the state}

Every society needs to determine the scope of government and, thus, the relation between the individual and the state. In the Western classical-liberal tradition, the individual precedes the state, and the primary function of government is to

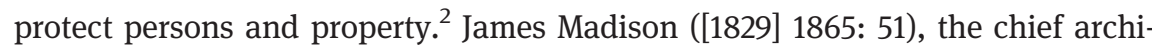
tect of the U.S. Constitution, regarded it as self-evident "that persons and property are the two great subjects on which governments are to act; and that the rights of persons, and the rights of property, are the objects, for the protection of which government was instituted."

A free private market is consistent with Madison's view of the role of government; market socialism is not. In China, the individual is subservient to the state, and the CCP is the dominant force. Regardless of rhetoric supporting individual rights and market reforms, the Chinese state still ultimately grants a higher prerogative to its own power than to individual freedom. The following passages from the PRC Constitution make it clear that socialism trumps capitalism and that the individual is subservient to the state:

- Article 1: The socialist system is the basic system of the People's Republic of China. Disruption of the socialist system by any organization or individual is prohibited.

2 This is not just a Western liberal idea. Mencius endorsed this view when he said, "The people are the most important element in a nation"; sometimes translated as, "The people are more important than the state” (Mencius 7B: 14). See Fung (1952: 113). 
- Article 7: The State-owned economy, namely, the socialist economy under ownership by the whole people, is the leading force in the national economy. The State ensures the consolidation and growth of the State-owned economy.

- Article 51: Citizens of the People's Republic of China, in exercising their freedoms and rights, may not infringe upon the interests of the State, of society or of the collective, or upon the lawful freedoms and rights of other citizens.

Although the present PRC Constitution recognizes the private sector and various human rights, it does not, and cannot, view private property and fundamental human rights as inalienable rights of individuals without destroying the Party's monopoly on power. Ultimately, all rights must be predicated to come from the state if the CCP is to retain its power and authority.

The challenge facing China is to establish what F. A. Hayek (1960) called a "constitution of liberty." Roger Pilon, who holds the B. Simon Chair in Constitutional Studies at the Cato Institute, has made this argument in a compelling fashion:

The freedom that the present [PRC] Constitution "permits," at the pleasure of the government, needs to be taken for granted - as a matter of right. What needs to be permitted, by a constitution, is government actions. Those actions need to be "authorized," in the strict sense of that word, and then carefully limited, much like the Chinese Constitution today authorizes, then strictly limits, individual liberty. What is needed, in short, is a constitution that starts at the other end of the matter [Pilon 1998: 341].

The good news is that despite the state's endemic, structural problems, China has made gradual progress in safeguarding persons and property during the reform movement. Under the old regime, Chairman Mao Zedong outlawed private property and free markets, forced people into communes, and destroyed civil society. People were instructed to "Strike hard against the slightest sign of private ownership” (Becker 2000: 157). Today, the Chinese people enjoy much greater economic freedom, which has also increased personal freedom.

Growing tensions between an increasingly vibrant private sphere and the continued socialist legacy on the behavior of the state has led to some structural reform. Notably, the PRC Constitution has been amended to recognize the importance of the nonstate sector and private property rights:

- Article 11: The non-public sectors of the economy such as the individual and private sectors of the economy, operating within the limits prescribed by law, constitute an important component of the socialist market economy.... The State protects the lawful rights and interests of the non-public 
sectors of the economy such as the individual and private sectors of the economy.

- Article 13: Citizens' lawful private property is inviolable.... The State, in accordance with law, protects the rights of citizens to private property and to its inheritance.

China's rising middle class has a strong incentive to protect their property rights, and this new vested interest will play a critical role in advancing economic and personal freedom. It would have been unimaginable under Mao for the CCP's Central Committee to express the view adopted at the Third Plenum:

We must actively and in an orderly manner promote market-oriented reform in width and in depth, greatly reducing the government's role in the direct allocation of resources, and promote resources allocation according to market rules, market prices and market competition [CCP 2013].

However, the real meaning of such language is qualified by a continued privileging of state power in matters of economics, society, and law. The CCP's proclaimed desire to expand the market and limit the state is thus sharply qualified by the reality that the CCP's monopoly on power depends on a top-down view of order rather than one based on freedom.

\section{Competing visions of freedom and order}

The role of institutions in supporting a free market cannot be underestimated. Institutional change in China has allowed greater freedom, but that freedom has been constrained by the lack of effective safeguards for persons and property. Justin Yifu Lin's admonition in 1998 that “it is essential for the continuous growth of the Chinese economy to establish a transparent, rule-based, legal system that protects property rights" has yet to be fulfilled (Lin 1998: 71).

Ideas and culture matter in the evolution of institutions (Zhang 2015a). One of the most important ideas for thinking about institutional change is the relationship between freedom and order.

\subsection{The view of market socialists}

The CCP holds that social and economic order is dictated by structures set by institutions of concentrated power, and that without order freedom is meaningless. According to the CCP, the chief role of the state is to establish order, not 
promote individual freedom, and for the state to establish order it must utilize mechanisms of state control. The priority of order and importance of control is deeply reflected in the PRC Constitution and in the Third Plenum's "Decision ... on Some Major Issues Concerning Comprehensively Deepening the Reform.” The later states:

To deepen the reform comprehensively, we must hold high the great banner of socialism with Chinese characteristics, follow the guidance of Marxism-Leninism, Mao Zedong Thought, Deng Xiaoping Theory, the important thought of the Three Represents and the Scientific Outlook on Development. We must have firm confidence, forge consensus, make holistic planning, and promote development in a coordinated way. We will uphold the direction of reform towards the socialist market economy, put the promotion of social fairness, justice and improvement of people's lives as the starting point and ultimate goal, further emancipate the mind, continue to release and develop the productive forces, release and strengthen vigor of the society, get rid of defects in various systems and mechanisms, and strive to open up broader prospects for socialism with Chinese characteristics [CCP 2013].

In other words, the Party is the driving force for institutional change in China, and all other goals are subservient to that of building "socialism with Chinese characteristics." Therefore, the CCP is not truly committed to a free market political economy, because in a truly liberal society institutional changes arise spontaneously.

While the Party pays lip service to a free market in ideas, noting "there can never be an end to the need for the emancipation of individual thought" (China Daily 2013), Party doctrine strictly regulates that market. Consequently, under market socialism, there is bound to be ever-present tension between the individual and the state. The arbitrariness and uncertainty of state action - and precariousness of private property and human rights - naturally breeds tension. The harmony that officials promise is a false harmony designed by the state, not a true harmony spontaneously produced by limited government and freedom.

President Xi Jinping, in a recent interview with the Wall Street Journal, expressed his view on the relationship between freedom and order: "Freedom is the purpose of order, and order the guarantee of freedom" (Xi 2015). There is some truth to this statement, but the real meaning is that China's ruling elite will not tolerate dissent - individuals will be free to communicate ideas, but only those consistent with "socialist principles."

\subsection{The view of market liberals}

In the tradition of market liberalism, freedom is not the purpose of order; it is the essential means to an emergent or spontaneous order. Simply put, voluntary 
exchange - based on the principle of freedom or nonintervention - expands the range of choices open to individuals and thus increases social wealth. ${ }^{3}$ As James M. Buchanan (1982: 5) has argued, “The 'order' of the market emerges only from the process of voluntary exchange among the participating individuals."

Of course, freedom requires rules, but not those chosen by an authoritarian government in a one-party state. Rather, the rules that support a free society are those that limit the power of government and protect the natural rights of individuals to their property while safeguarding the equal rights of others to life, liberty, and property.

In 1776, Smith argued that if "all systems either of preference or of restraint" were "completely taken away," a "simple system of natural liberty" would evolve "of its own accord." Each individual would then be "left perfectly free to pursue his own interest in his own way, and to bring both his industry and capital into competition with those of any other man, or group of men," provided "he does not violate the laws of justice" (Smith [1776] 1937: 651).

Friedrich Hayek (1967: 162) called this idea of spontaneous order "the central concept of liberalism" and noted:

Under the enforcement of universal rules of just conduct, protecting a recognizable private domain of individuals, a spontaneous order of human activities of much greater complexity will form itself than could ever be produced by deliberate arrangement, and in consequence the coercive activities of government should be limited to the enforcement of such rules.

In China, the tension between state and market, or between the individual and the state, stems from a failure to recognize that order is derived from freedom under a just rule of law, not from commands and the force of law.

When Xi Jinping says, “An important goal for China's current economic reform is to enable the market to play the decisive role in resource allocation and make the government better play its role," he recognizes that China needs "to make good use of both the invisible hand and the visible hand" (Xi 2015). The problem is that the invisible hand doesn't work well without the freedom that stems from widespread private property and limited government. ${ }^{4}$

3 Peter Bauer, a pioneer in development economics, held that "the principal objective and criterion of economic development" is to widen "the range of effective alternatives open to people" (Bauer 1957: 113). He understood that "the market order minimizes the power of individuals and groups forcibly to restrict the choices of other people," and that under such a spontaneous order "the rich ... usually owe their prosperity to activities which have widened the choices of their fellow men, including those of the poor" (Bauer 1984: 25).

4 On the primacy of property in a liberal order and the lessons for China, see Dorn (2003). 


\section{From market socialism to market Taoism}

In moving from market socialism to market liberalism, or what I call "market Taoism" (Dorn 1998), China needs to return to its ancient culture and cultivate the liberal ideas of thinkers such as Meng Tzu (Mencius), Lao Tzu, Chuang Tzu, and Han Fei Tzu, all of whom recognized the importance of freedom in promoting a harmonious social order.

CCP leaders consistently invoke classical Chinese philosophy as validation for the authoritarian aspects of the modern Chinese state. These leaders often argue that freedom and liberalism are Western ideologies, and that calls for increased freedom and liberalization in China are an undue form of cultural imperialism and a Western attempt to undermine Chinese sovereignty and prosperity. In reality, the idea that Eastern philosophy uniformly supports topdown imposed order is a political creation of the CCP, designed to justify its authoritarian power. The CCP relies on a cherry picked reading of classical Chinese writers; a more holistic review demonstrates the presence and importance of ideas we would now classify as liberal. These writings show that free markets, private property, and laissez faire are not a modern, Western ideology, but a universal reflection of an innate human desire for freedom. ${ }^{5}$

Although President Xi Jinping has said, "We need to fully make use of the great wisdom accumulated by the Chinese nation over the last 5,000 years" (cited in Page 2015), his attention has been on using classical literature to strengthen the Party's adherence to socialism, not to promote the market's invisible hand and freedom. As he says, "We in the Communist Party are firm Marxists and our party's guiding thought is Marxism-Leninism, Mao Zedong Thought and Socialism with Chinese Characteristics" (cited in Tatlow 2014).

President Xi draws on Confucian thought to support the view that the partystate should impose virtue on the people, and he relies on Han Fei to argue for the force of law to rule the people. Yet he ignores the fact that Han Fei sought to integrate Taoism with a liberal Legalism, and viewed law as an instrument for enhancing freedom - not for repressing the people. ${ }^{6}$

5 See, for example, Rothbard (2006: 23-27) and McCormick (1999b).

6 Han Fei is often viewed as an authoritarian of the Legalist School who only sees law as an instrument of force. Didi Kirsten Tatlow (2014), in an article in the New York Times, writes: "Mr. Xi has drawn on the teachings of Han Fei, the Legalist philosopher who advocated rule with an iron fist." 


\subsection{The Tao of the market}

Lao Tzu's philosophy of wu wei (noninterference or freedom) and the emergence of spontaneous order (harmony) when people are left alone to pursue their own happiness and prosperity is captured in the following passage from the Tao Te Ching:

The more restrictions and limitations there are, the more impoverished men will be.... The more rules and precepts are enforced, the more bandits and crooks will be produced. Hence, we have the words of the wise: Through my non-action, men are spontaneously transformed. Through my quiescence, men spontaneously become tranquil. Through my non-interfering, men spontaneously increase their wealth. ${ }^{7}$

The principle of noninterference is the principle of freedom; it is the "principle of spontaneous order" that Nobel laureate economist James M. Buchanan (1979: 81-82) has called "the most important central principle in economics."

Lao Tzu, who lived in the sixth century, B.C., never developed the notion of spontaneous market order to the extent that Adam Smith did in the Wealth of Nations, written more than 2,000 years later. Nevertheless, one could argue that it is as if Smith's notion of the "invisible hand" of market competition leading to social and economic order has similarities in Taoist thought. ${ }^{8}$ Like Smith, Lao Tzu recognized that an over-regulated economy and excessive taxes discourage production, erode freedom, and disrupt social and economic order: "When taxes are too high, people go hungry. When the government is too intrusive, people lose their spirit. Act for the people's benefit. Trust them; leave them alone."

China's leaders and people can turn to Lao Tzu for guidance. His opposition to government intervention and his powerful idea of spontaneous order are just as relevant today as they were in ancient China. As Wing-Tsit Chan, a prominent Chinese philosopher notes, the Tao Te Ching "strongly opposes oppressive government." The "sage-ruler" should guide by "noninterference" (wu wei). Thus, "Taoism is ... not a philosophy of withdrawal. Man is to follow Nature but in doing so he is not eliminated; instead, his nature is fulfilled" (Chan 1963: 137). It is in this sense that Lao Tzu believed that "when the government is non-discriminative and dull, the people are contented and generous." But "when the

7 This passage is a translation of Chapter 57 by Chang Chung-yuan (1975: 143). It is important to note that 'wu wei, 'non-activity,' does not really mean the complete absence of all activity, but only of such as is forced, artificial, and unspontaneous" (Bodde 1952: xxiii).

8 Smith ([1776] 1937: 423) held that often an individual pursuing his own self-interest is "led by an invisible hand to promote an end which was no part of his intention. Nor is it always the worse for the society that it was not part of it."

9 Chapter 75, Tao Te Ching, translated by Mitchell ([1998] 1991). 
government is searching and discriminative, the people are disappointed and contentious."

Like Lao Tzu, his follower Chuang Tzu (Zhuangzi or Master Zhuang) adhered to the idea that harmony is best achieved by leaving people alone to pursue their own interests. He believed that each individual is unique, seeks a better life, and is naturally inclined toward peace and order. He opposed forced order/stability and adhered to the principle of freedom. ${ }^{11}$ As Fung (1952: 229) writes, "Since good order is generally desired, one need only let things alone, and good order will result spontaneously. Thus Chuang Tzu, like Lao Tzu, advocated government through non-government." This view of freedom and order is in sharp contrast to Xi Jinping's notion that "freedom is the purpose of order."

During the Han dynasty (206 B.C. to 220 A.D.), the great historian Sima Qian, in his famous Records of the Historian, recognized the importance of markets and the division of labor in enhancing individual and social wealth - and the ruinous effect of government meddling and central planning:

\begin{abstract}
There must be farmers to produce food, men to extract the wealth of mountains and marshes, artisans to produce these things, and merchants to circulate them. There is no need to wait for government orders: each man will play his part, doing his best to get what he desires.... When all work willingly at their trade, just as water flows ceaselessly downhill day and night, things will appear unsought and people will produce them without being asked. For clearly this accords with the Way and is in keeping with nature.
\end{abstract}

This passage, cited in Young (1996: 138), provides further evidence that long before the eighteenth century Scottish Enlightenment, China had already developed the idea of spontaneous order and grasped Adam Smith's invisible hand. ${ }^{12}$

\title{
5.2 Spontaneous order and the rule of law
}

Spontaneous order is not independent of the institutions within which individuals make choices. Those institutions include both formal and informal rules, including moral codes and cultural norms. Confucian ethics were an important part of China's ancient culture. They emphasized that great leadership depended

10 Chapter 58, Tao Te Ching, translated by Chan (1963: 167).

11 For a more detailed discussion of Chuang Tzu's Taoist philosophy, see Fung (1952): chap. 10. 12 Chinese-American Gregory C. Chow (Zhou Zhizhuang) of Princeton University argues that this quotation (from "The Biographies of the Money Markets") "suggests that Sima had a deep understanding of the workings of the market economy." Indeed, "It might be difficult to find a passage in Adam Smith's Wealth of Nations that provides a clearer and simpler description of a market economy" (Chow 2007: 13). See also Spengler (1964) and McCormick (1999a). 
on the virtue of the leader and that if the leader was not virtuous he would lose the "mandate of heaven."

Lao Tzu went further and taught that if leaders did not interfere with the natural desire of individuals to make themselves better off, then things would go smoothly and wealth would appear without state supervision.

Han Fei Tzu, a leading Legalist scholar in the third century, B.C., accepted the Taoist notion of spontaneous order but emphasized that - given the nature of man - rules are necessary to make sure freedom leads to socially beneficial results by limiting the power of the state and ensuing equality under the law. Hence, he understood that without a genuine rule of law, China could not create a truly harmonious society.

Han Fei saw individuals as purposive - that is, as self-interested actors seeking to improve their well-being. This could be done by theft or by voluntary exchange. To bring about harmony, laws would have to be enforced to protect against plunder by both individuals and the state. Like James Madison, Han Fei started with the premise that men are not angels: they need rules to prevent them from injuring others.

The central difficulty facing Han Fei was the same one facing Madison, who in Federalist No. 51 wrote: "In forming a government which is to be administered by men over men, the great difficulty lies in this: you must first enable government to control the governed; and in the next place oblige it to control itself." Madison and the Framers of the U.S. Constitution resolved this difficulty by establishing a constitutional republic. ${ }^{13}$ Han Fei blended the Taoist idea of wu wei with the need for "necessary principles" of law $(f a)$, method (shu), and power (shih).

Fung Yu-lan, in his classic History of Chinese Philosophy, gives a detailed account of Legalism and tells us that the ideal was "great good government" (Fung 1952: chap. 13). If everyone is subject to the law and people are free to choose, society would benefit and the people would prosper. That ideal has never been realized in China and the Legalist School has often been misinterpreted. ${ }^{14}$ China's leaders have used Legalism to serve their own interests, not to protect the Chinese people.

A virtuous leader is not a precondition for social order. What matters the most for social and economic harmony is an institutional infrastructure based on what F. A. Hayek (1982) called "rules of just conduct.” Han Fei recognized the

13 For a detailed discussion of Madison's constitutional political economy, see Dorn (1991). 14 In a recent article in the Financial Times, for example, Isabel Hilton (2015: 7) holds that Han Fei "saw the law not as a guarantee of justice but as a coercive instrument in a state in which the moral standards of the ruler were irrelevant." Law is no doubt "a coercive instrument," but Han Fei viewed the law as an instrument to prevent harm, not to promote injustice. 
need for such rules long before western thinkers, but his thought has been distorted by rulers who seek power over freedom.

Han Fei's ideas about human nature and the role of rules to bring about social harmony are remarkably like those of Adam Smith. In Chapter 32 of what is known as the Han Fei Tzu (a collection of Han Fei's, and probably other Legalists' teachings), we find the following passage:

When a man sells his services as a farm hand, the master will give him good food at the expense of his own family, and pay him money and cloth. This not because he loves the farm hand, but he says: "In this way, his ploughing of the ground will go deeper and his sowing of seeds will be more active.” The farm hand, on the other hand, exerts his strength and works busily at tilling and weeding. He exerts all his skill cultivating the fields. This is not because he loves his master, but he says: "In this way I shall have good soup, and money and cloth will come easily." Thus he expends his strength as if between them there were a bond of love such as that of father and son. Yet their hearts are centered on utility, and they both harbor the idea of serving themselves. Therefore in the conduct of human affairs, if one has a mind to do benefit, it will be easy to remain harmonious, even with a native of Yüeh [a barbarian state]. But if one has a mind to do harm, even father and son will become separated and feel enmity toward one another [Fung 1952: 327].

This extract clearly shows that Han Fei accepted Taoist ideas similar to the modern concept of spontaneous order and recognized the importance of voluntary exchange. He also recognized men could do evil and, therefore, peace and prosperity require a government bound by equal laws of justice. In Chapter 50, he says: "If one makes it so that the people can do no wrong, the entire state can be kept peaceful” (Fung: 330). Thus, while Han Fei welcomed Confucian virtue, he did not think it sufficient to prevent harm.

The power (shih) of the ruler was not to be unlimited; it was to be used in a just manner through the law $(f a)$ and methods (shu) - a system of punishments and rewards - which constitute the "necessary principles" of "great good government." The key idea, notes Fung (1952: 330), is that "if the ruler can utilize these principles, he will be able to rule through non-activity (wu wei)."

In other words, order flows from freedom under the law. Rulers who use their power wisely to prevent harm while allowing people the freedom to pursue their own interests will create social and economic harmony. In Chapter 29 of the Han Fei Tzu, we learn that ancient rulers who adhered to the necessary principles of good government

relied for good government ... upon laws and methods; let right and wrong be dealt with by rewards and punishments; and referred lightness and heaviness to the balance of the scale. They did not oppose the natural order, and did not inflict injury upon human feelings and nature.... They did not press what is beyond the law, or let loose what is within it. They kept to the proper order, and responded to the spontaneous.... The responsibilities for glory or disgrace depended upon the individual, and not on others [Fung: 331]. 
Further evidence that Han Fei did not want to use the law to suppress people but to make them responsible and free to pursue their self-interest, which he thought would spontaneously produce a harmonious society, is found in Chapter 11 of the Han Fei Tzu: "Scholars skilled in the law must have strong resolution and unyielding uprightness.... [They must] be able to rectify the wicked conduct of powerful men” (Fung: 335). In Chapter 42, Han Fei says,

I believe that by setting up laws and methods, and establishing standards and measures, I can benefit the people and ease their way. Therefore, I fear not the calamity of incurring the wrath of a disorderly or unenlightened superior, but must first think of how to make wealth and profit adequate for the people.... I cannot endure the report of acting avariciously and meanly, and dare not harm the course of morality and knowledge [Fung: 336].

Han Fei, in Chapter 50, warned against a redistributive state, which he thought would dull incentives to save and be productive. Taking property from an industrious person and redistributing it to a wasteful person via the state, he said, would decrease the wealth of the nation. As Fung (1952: 328) notes, "In economics, Han Fei Tzu holds that since all men act in their own interests, it is better to leave them alone in free competition. Therefore, he opposes the Confucian doctrine of the equal division of land." 15

The emphasis of many members of the Legalist School was on uniformity of the laws and equal justice under the law. The laws were to apply equally to all: "If the law is not uniform, there will be misfortune for the holder of the state.... Therefore, it is said that the law must be kept constant.... When ruler and minister, superior and inferior, noble and humble all obey the law, this is called having Great Good Government."16

The merging of Legalism and Taoism - to show the importance of rules and institutions for the emergence of a spontaneous social and economic order provides strong lessons for China's current leaders. ${ }^{17}$ By turning to Han Fei's liberalism, leaders would find support for adopting market Taoism and for letting people be free to choose under a just rule of law. A truly harmonious society could then be realized.

15 Mencius, a Confucian, placed relatively more attention on individual freedom than Confucius (Fang 1952: 127). He supported the rights of merchants to engage in exchange, opposed excessive taxes, defended free-market prices, and recognized the importance of the division of labor (Schwartz 1985: 279).

16 From Chapter 45 of the Kuan Tzu (Fung 1952: 322).

17 For further analysis of the merging of Legalism and Taoism, see Schwartz (1985: 343-44). According to Schwartz (246-47), Shen Tao may have been the first "to fuse Taoist and Legalist themes." However, he did not have the breadth and depth of Han Fei. 
What China needs is a free market in ideas, as expounded by Coase and Wang (2012). "Let a thousand flowers bloom" - and continue to bloom - so that the Chinese people can learn about alternatives to an authoritarian state by turning to the writings of Lao Tzu and Han Fei Tzu, as well as classical liberals in the west.

With new thinking (xin si wei), China can resolve the problem of institutional incompatibility and adopt a constitution that effectively limits the power of government and enshrines the principle of freedom/nonintervention (wu wei).

One idea that would be valuable in transforming China from market socialism to free private markets is to apply the principle of "rectification of names and actualities" to the rulers. The original doctrine was meant to ensure uniformity and help the sage-ruler govern the people by requiring that individuals keep their promises to do what they are supposed to do - that is, to adhere to their prescribed duties so that names and actualities mesh. If an individual failed to fulfill his duties as prescribed, he would be punished; if he fulfilled his duties, he would be rewarded. In this way the ruler could use "two handles" (penalties and rewards) to bring about order. ${ }^{18}$ As the Kuan Tzu states, "When names and actualities are in agreement, good government results; when they are not in agreement, disorder results" (Fung 1952: 324).

If applied to rulers, the rectification of names and actualities would mean China's leaders would have to honor the straight-forward meaning of words, and thus actualize the promises made in the PRC Constitution to allow individuals freedom of speech and to safeguard property rights. The following two articles would then become meaningful:

- Article 35: Citizens of the People's Republic of China enjoy freedom of speech, of the press, of assembly, of association, of procession and of demonstration. - Article 37: Freedom of the person of citizens of the People's Republic of China is inviolable.

At a press conference following the Third Session of the 12th National People's Congress (NPC), Premier Li Keqiang (2015) said, "We need to ensure that we run the country according to the law - everyone is equal before the law, and no one is above the law.... There must be no irresponsible actions or inaction on the part of government officials." He wants people to "achieve full potential in their life," and have the government "eliminate roadblocks and pave the way for people to tap their entrepreneurship." Finally, he would fight

18 According to the Han Fei Tzu, Chapter 7, "When a ruler wishes to prevent wickedness, he examines ... the correspondence between actualities and names, words and work" (Fung 1952: 324). Rewards and punishments are used to ensure that individuals honor their word and that words (names) match deeds. "The way in which the intelligent ruler leads and governs his subjects is by means of two handles. These two handles are penalty and benevolence” (chap. 7; Fung: 326). 
corruption and rent-seeking by "institution-building." If the principle of rectification of names and actualities were applied to Premier Li, his rhetoric would have to match his actions - or he would not keep his job.

\section{Conclusion}

The CCP's decision to turn from class struggle to economic development as the key Party platform has been highly successful, allowing China to achieve double-digit growth and become the world's largest trading nation. That growth was ignited by the spontaneous development of the non-state sector (Coase and Wang 2012, Lardy 2014, Zhang 2015b). Nevertheless, China's adherence to market socialism persists, and the resulting "institutional incompatibility" has yet to be resolved by establishing "a transparent legal system that protects property rights” (Lin, Cai, and Li 1996: 226).

The recent slowing of China's growth and waning trust in the CCP's ability to "stabilize the market," as evidenced by the sharp drop and volatility in stock prices, pose a danger to China's leaders. The challenge, as Premier Li (2015) said in his press conference is "to get the relationship right between the government and the market." The Party must, in Li's words, defeat vested interests, which is like "taking a knife to one's own flesh."

Moving toward a legal system in which "no one is above the law" is important, but it is even more important to ensure that the law itself is just, in the sense of protecting equal rights to life, liberty, and property. The idea of freedom under the law is not solely a western concept; it goes back to Han Fei and other Chinese thinkers who conceived the notion of spontaneous order and the role of rules in creating that order.

Premier Li's call for boosting the "vitality of the market" sends a strong signal that what China needs is more freedom and less state power. Adherence to the principles of market Taoism, rather than market socialism, would offer China's leaders and people an alternative that is consistent with their own culture as well as with the "free private markets” favored by Milton Friedman (1990: 125) and Adam Smith.

\section{References}

Buchanan, J. M. 1979. "General Implications of Subjectivism in Economics," in J. M. Buchanan (ed.) What Should Economists Do? pp. 81-91. Indianapolis: Liberty Press.

Buchanan, J. M. 1982. “Order Defined in the Process of Its Emergence,” Literature of Liberty 5(4): 5-18. Available at http://oll.libertyfund.org/titles/liggio-literature-of-liberty-winter-1982-vol-5-no-4. 
Bauer, P. T. 1957. Economic Analysis and Policy in Underdeveloped Countries. Durham, N.C.: Duke University Press.

Bauer, P. T. 1984. Reality and Rhetoric: Studies in the Economics of Development. Cambridge, Mass.: Harvard University Press.

Becker, J..2000. The Chinese. New York: The Free Press.

Bodde, D. 1952. "Revisions and Additions for the Second Edition." In Fung (1952: xxi-xxxiv).

Chan, W. T. 1963. A Source Book in Chinese Philosophy. Princeton, N. J.: Princeton University Press.

Chang, C. Y. 1975. Tao: A New Way of Thinking. A Translation of the Tao Te Ching with an Introduction and Commentaries. New York: Perennial Library/Harper and Row.

Cheung, S. N. S. 1982. Will China Go 'Capitalist'? London: Institute of Economic Affairs (2d ed. with "Postscript" published in 1986.)

Cheung, S. N. S. 1990. "Privatization vs. Special Interests: The Experience of China's Economic Reforms," In J. A. Dorn, and X. Wang (eds.) Economic Reform in China: Problems and Prospects, pp. 21-32. Chicago: University of Chicago Press.

China Daily. 2013. "The decision on major issues concerning comprehensively deepening reform in brief." China Daily (16 November). Available at www.china.org.cn/china/third_ plenary_session/2013-11/16/content_30620736.htm.

Chinese Communist Party (CCP) Central Committee. 2013. "Decision of the Central Committee of the Communist Party of China on Some Major Issues Concerning Comprehensively Deepening the Reform." Adopted at the Third Plenary Session of the 18th Central Committee of the Communist Party of China (12 November). Available at www.china.org. cn/china/third_plenary_session/2014-01/16/content_31212602.htm.

Chow, G. C. 2007. China's Economic Transformation, 2nd ed. Malden, Mass.: Blackwell.

Coase, R., and Wang, N. 2012. How China Became Capitalist. New York: Palgrave Macmillan.

Constitution of the People's Republic of China (Full Text after amendment on March 14, 2004). Available at http://www.npc.gov.cn/englishnpc/Constitution/node_2825.htm.

Deng, X. P. 1987. Fundamental Issues in Present-Day China. Translated by the Bureau for the Compilation and Translation of Works of Marx, Engels, Lenin, and Stalin under the Central Committee of the Communist Party of China. Beijing: Foreign Languages Press.

Dorn, J. A. 1991. "Madison's Constitutional Political Economy: Principles for a Liberal Order," Constitutional Political Economy 2(2): 163-86.

Dorn, J. A. 1998. “China's Future: Market Socialism or Market Taoism?” Cato Journal 18(1): 131-46.

Dorn, J. A. 2003. "The Primacy of Property in a Liberal Constitutional Order," The Independent Review 7(4): 485-501.

Friedman, M. 1990. Friedman in China. Shatin, N.T., Hong Kong: The Chinese University Press for the Hong Kong Centre for Economic Research.

Fung, Y. L. 1952. A History of Chinese Philosophy. Vol. 1: The Period of the Philosophers, 2nd ed. Translated by D. Bodde. Princeton, N. J.: Princeton University Press. Originally published in Chinese in 1931 by the Shen Chou Publishing Company, Shanghai.

Hayek, F. A. 1960. The Constitution of Liberty. Chicago: University of Chicago Press.

Hayek, F. A. 1967. "The Principles of a Liberal Social Order," In Studies in Philosophy, Politics, and Economics, pp. 160-77. Chicago: University of Chicago Press.

Hayek, F. A. 1982. Law, Legislation, and Liberty, 3 vols. London: Routledge and Kegan Paul. Hilton, I. 2015. "Ancient Origins of Xi's Harsh Brand of Justice." Financial Times

17 August: 7. 
Lardy, N. R. 2014. Markets over Mao: The Rise of Private Business in China. Washington: Peterson Institute for International Economics.

Li, K. Q. 2015. “Full Transcript of Premier's Press Conference.” Available at http://english.gov. cn/premier/news/2015/03/15/content_281475071837425.htm. (The press conference followed the Third Session of the 12th National People's Congress, March 15, 2015.)

Lin, J. Y. 1998. "The Current State of China's Economic Reforms," in J. A. Dorn (ed.) China in the New Millennium: Market Reforms and Social Development, pp. 39-74. Washington: Cato Institute.

Lin, J. Y., F. Cai, and Z. Li. 1996. "The Lessons of China's Transition to a Market Economy," Cato Journal 16(2): 201-31.

Madison, J.. [1829] 1865. "Speech in the Virginia State Convention of 1829-30, on the Question of the Ratio of Representation in the Two Branches of the Legislature," December 2, 1829. in J. Madison (ed.) Letters and Other Writings of James Madison, vol. 4, pp. 1829-36. Philadelphia: J. B. Lippincott.

McCormick, K. 1999a. "Sima Qian and Adam Smith," Pacific Economic Review 4(1): 85-7.

McCormick, K. 1999b. “The Tao of Laissez Faire," Eastern Economic Journal 25(3): 331-41.

Mitchell, S. ([1998] 1991) Tao Te Ching: A New English Version. New York: Harper Perennial. Originally published in 1998 by Harper and Row.

Page, J. 2015. "In China Confucius Makes a Comeback," Wall Street Journal (21 September): A1.

Pilon, R. 1998. "A Constitution of Liberty for China," in J. A. Dorn (ed.) China in the New Millennium: Market Reforms and Social Development, pp. 333-53. Washington: Cato Institute.

Rothbard, M. N. 2006. Economic Thought before Adam Smith: An Austrian Perspective on the History of Economic Thought, vol. 1. Auburn, AL: Ludwig von Mises Institute. First published by Edward Elgar, 1995. Available at https://mises.org/library/austrian-perspectivehistory-economic-thought.

Schwartz, B. I. 1985. The World of Thought in Ancient China. Cambridge, Mass.: Belknap Press, Harvard University Press.

Smith, A.. [1776] 1937. The Wealth of Nations. Edited by E. Cannan. New York: The Modern Library (Random House).

Spengler, J. J.. 1964. “Ssu-Ma Ch'ien: Unsuccessful Exponent of Laissez-Faire," Southern Economic Journal 30(3): 223-43.

Tatlow, D. K. 2014. "Xi Jinping on Exceptionalism with Chinese Characteristics." New York Times.com (14 October). Available at http://sinosphere.blogs.nytimes.com/ 2014/10/14/xi-jinping-on-exceptionalism-with-chinese-characteristics.

Wei, L. 2015. "China to Overhaul State Sector," Wall Street Journal (14 September): A1.

Xi, J. P. 2015. “In Rare Interview, Xi Discusses Ties with the U.S.," Wall Street Journal 22 (September): A11.

Young, L. 1996. "The Tao of Markets: Sima Qian and the Invisible Hand," Pacific Economic Review 1(September): 137-45.

Zhang, W. Y. 2015a. "The Power of Ideas and Leadership in China's Transition to a Liberal Society," Cato Journal 35(1): 1-40.

Zhang, W. Y. 2015b. The Logic of the Market: An Insider's View of Chinese Economic Reform. Translated by M. Dale. Washington: Cato Institute.

Zhou, K. X.. 1996. How the Farmers Changed China. Boulder, Colo.: Westview Press. 


\section{Bionote}

\section{James A. Dorn}

James A. Dorn is a Senior Fellow and China specialist at the Cato Institute in Washington, D.C. This paper was first presented at conferences in Shenzhen and Hong Kong in November 2015. The author thanks Steven N. S. Cheung, the Ronald Coase Centre for Property Rights Research at the University of Hong Kong, and the Ronald Coase Center for the Study of the Economy at Zhejiang University for organizing those conferences. He also thanks Kevin Dowd, Ari Blask, and Timothy Beardson for helpful comments on earlier drafts. 